Article History:

Received: July 1, 2020

Revised: August 10, 2020

Accepted: August 24, 2020 https://doi.org/10.3126/pycnjm.v13i1.31493

PYC Nepal Journal of Management

Vol. XIII, No. 1, Page: 17-32

ISSN:2091-0258

\title{
Work-Culture for Employee Work-Behaviour: Mediating Role of Satisfaction
}

\author{
Prakash Kumar Gautam'
}

:0000-0002-2197-3851

\begin{abstract}
Culture is the enduring set of values, beliefs and work principles guiding overall organizational behaviour. Employees' behaviours are the consequences of work-culture as they behave reciprocal of their experience. This study establishes unique relationship among work-culture, employee satisfaction and work-behaviour in Small and Medium Enterprise (SMEs). Structured questionnaire was used to collect the data from 376 respondents. Confirmatory Factor Analysis was used to examine the model significance with validity, regression analysis to test the direct relationship while Preacher and Hayes Process Macro approach for examining mediation effect. This study revealed the work-culture significantly influenced employees'satisfaction and work-behaviour with no moderation effect of job satisfaction. Findings of this study suggest managers to promote supportive work-culture to increase employee satisfaction and positive work-behaviour. This study also provides evidence to strengthen a reciprocity approach of social exchange theory (SET) in employees' work-behaviour in SMEs.
\end{abstract}

Key words: Bureaucratic culture, Employee satisfaction, Innovative culture, Supportive culture, Work-behaviour, Work-culture.

\section{INTRODUCTION}

Small and Medium Enterprises (SMEs) poses a significant contribution to a nation's economy - manufacturing, employment generation, export and GDP growth (Bista, 2019), in Nepal, it has 22 percent contribution in GDP as on F/Y 2018/19 with 275,433 new SMEs registration contributing 60 percent of total employment generation. But the business environment is constantly changing with immense challenges because of global,

1. Mr. Gautam is a Lecturer at Shanker Dev Campus, Faculty of Management, Tribhuvan University, Nepal. He can be reached at Prakash.gautam@sdc.tu.edu.np. 
regional as well as domestic forces. Not only in Nepal, failure rate of SMEs globally is high; 22 percent SMEs fail within a year of registration and 66 percent fail within six years of time (Spinelli \& Adams, 2016). Poor institutional development, high cost of capital, lack of professional experience and qualification, poor people management and outdated technology used are more important internal challenges and competition and poor institutional support are the external factors hindering the growth of enterprises. Managing people could be the only way to reduce other weaknesses to cope with challenges.

Organizational leaders do believe that the cut-throat competition in market creates threats to the business but the research works have proven that positive organizational psychology creates dramatic benefits not only to the employers but also to the employees and bottom line (Seppälä \& Cameron, 2015) justifying the people management as important tool to succeed or fail the business organizations. As a result, work culture, as predictor of employees' satisfaction, is being the central issue of research as it influences employees' attitude; as 90\% employees reported as they were just satisfied and only $40 \%$ reported very satisfied in Gallup Survey (Libraries , 2020). Unlike large organizations, SMEs need to maintain special work-culture to motivate employees for innovative and committed work behaviour so that human related problems of deviant behaviour, absenteeism and turnover can be managed. For employee satisfaction, commitment for sustainable growth of SMEs, there should be effective employee relations in the organization comprising awareness, action, comprehensiveness, and excellence (Maheshwari, Samal, \& Bhamoriya, 2020). SMEs need to focus on micro analysis of people management at workplaces which hints at the need to enhance work-culture. In view of this background and general observation of a large number of SMEs failure, ownership transfer and higher rate of employees' turnover, a research question can be formulated as to whether work-culture is responsible for creating employees' satisfaction and their commitment for organizational betterment. This research work aims to examine the role of creating suitable work-culture to satisfy employees and orient their behaviour for the betterment of a business enterprise.

\section{LITERATURE REVIEW}

Industrial Policy of Nepal 2010 has classified Nepali industries into four categories as Micro Enterprises, Small Industries, Medium Industries, and Large Industries based on size of investment capital as up to Rs. 0.2 million, up to 50 million, Rs. 50 - Rs. 150 million, and more than Rs. 150 million including land and building respectively (Industrial Policy, 2010). SMEs comprise their business in their regular involvement, with little plans and policies. In Nepal, there is majority of SMEs but are less privileged by state facilities. They need to manage finance, technology, market and people on their own and the people management is being more challenging.

Work-culture is responsible in satisfying employees for their positively behaviour (MSG, 2020) for organizational purpose. Employee work behaviour (WB) is the extent 
of employees' reaction to a particular work situation (MSG, 2020), policy and working pattern at workplace on a regular basis. It is obvious that each employee should behave responsibly for the betterment of business, organization, customers and probably of their own. Positive behaviour of employees always accepts the organizational policies, and advocates organization's goods and services (show positive word of mouth) and helps to maintain good working environment, respects organizational value system, working pattern and organizational decisions positively. Positive employees always try their best to satisfy their customers through their innovative and supportive behaviour. Reversely, negative employees disobey organizational decisions, refuge changes, shout open fellow employees, criticize supervisors and managers, spread rumours, and even show unprofessional work behaviour to the customers. Thus, for organization's success, workculture is vital as it is vital to create employees' positive behaviour.

Work commitment, as proxy of work behaviour, is the promise or guarantee of attachment that an employee feels towards the long run professional relationship. Commitment is an effective attachment of employees to the organization gives them full energy to fulfil the organizational goals (Buchanan, 1974). It is employee's emotional attachment to, identification with, and involvement in the organization and its goals. Work commitment is employee's psychological state which characterizes continuing involvement and engagement with job responsibility as well as membership for nonterminating professional relationship with the working organisation; not only under any favourable circumstances but also in unfavourable situations affecting the organisation (Meyer \& Allen, 1997). Dessler (1999) ascertains that committed employees tend to have not only high attendance records but also longer job tenure in comparison to less committed employees. Commitment induces willingness in employees to give their best energy with fullest loyalty to solve organizational problems and maintain organizational system.

Commitment is the result of value congruency between individual and organization (Tabane, Bosch, \& Roodt, 2013). It is the behavioural consequence of strong belief of an employee in and acceptance of organizational values, goals and working relationships. Organizational commitment is the result of good human resource management practices (Mathieu \& Zajac, 1990). Such congruency in values, a person feels psychological attachment with organizational goals, working procedures and work-relations. Gautam (2017) suggests that use of the best human resource practices as a component of strategic human resource management helps to maintain employees' commitment. Employees' commitment shapes unique set of behaviours in individual, group, team and organization level. It insists to show organizational citizenship behaviour; advocating organization's products and culture positively. Different research works have established a significant influence of commitment on pro-social behaviour (O'Reilly \& Chatman, 1986), absenteeism (Angle \& Perry, 1981) and turnover intention (Poznanski \& Bline, 1997). Thus, for positive behaviour and commitment of the employees for organizational success, managers must commit to ensure organization-person value congruency through maintaining best work-culture. 
Work culture is the subset of organizational culture, comprised with shared understanding of the beliefs, values, norms and philosophies of how things work (Wallach, 1983). It is established with long experience and practices and comparatively is enduring. Work culture is unique for every organization which is much difficult to change (Robbins \& Judge, 2013). Work-culture (WC) is the micro analysis of organizational culture at work-level examining the extent of support, care and pleasant work environment. WC helps to attract and retain competent and dedicated employees to the organization (Sidekicker, 2020). WC creates a congenial working environment to develop work satisfaction, professional relationship and performance progression. In general, WC is the blend of organization's value, traditions, beliefs, leadership traits, communication patterns, employee participations, behaviours and attitudes frequent to deliver in work stations as self-understood working principles. WC generally, is not necessary to have in written form as what are norms, values and protocols in work place rather these things are well understood and followed automatically by each person as work principles.

A number of researchers (Kalemci, Kalemci-Tuzun, \& Ozkan-Canbolat, 2019; Zakayo, 2018; Dessler, 1999; Fiorita, Bozeman, Young, \& Meurs, 2007) have laid their focus on linking culture, employee satisfaction, commitment and performance. In the past decades, organizational culture was at the centre of research interest because of its influence on organizational processes (Rashid, Sambasivan, \& Johari, 2003). It provides base line for identifiable work attitudes, norms and values of each individual associated in the organization. Organizational culture affects organization and behaviour of people in number of ways like employees interact with subordinates, superordinate, co-workers, customers and other stakeholders. Culture serves as a source for internal sense making (Ravasi \& Schultz, 2006) regarding what is expected from them and what they need to do. Organizational culture influences the job satisfaction and organizational commitment (Lok \& Crawford, 2004) as most significant output of organizational culture which has influenced the organizational performance through employees' performance. Cameron and Quinn (2011) reported that, in addition to organisation-level effects, organizational culture influences on key employee attitudes. Workplace situational factors (Hershcovis, et al., 2007) like injustice, interpersonal conflict, situational constraints, as well as leadership ineffectiveness as determinants of workplace culture cause employees' aggression i.e. negative work behaviour. Organizational politics as component of work culture is the most influential factor to set the employees' job satisfaction and work behaviour i.e. commitment (Miller, Rutherford, \& Kolodinsky, 2008; Samwel, 2018). As the element of work-culture, person-job fit initiation practices also play a vital role in employees' satisfaction and commitment (Kristof-Brown, Zimmerman, \& Johnson, 2005; Verquer, Beehr, \& Wagner, 2003). Work-culture leads to the employee relations which causes on important element of employees' commitment, and performance (Samwel, 2018) which may lead organizational prosperity and sustainability. Among the other challenges, SMEs face challenge of employee management with fair labour 
practices, equitable benefit sharing, and unbiased growth opportunity resulting poor employees' commitment and sustainable employee-employer relationship. It is most important to understand the culture of an organization to remove all the challenges facing and prone to face in pace of organizational changes (Isa, Ugheoke, \& Noor, 2016).

Employee relations based on cultural pattern influence on their morale and motivation (Zakayo, 2018). Aligning with fixed or few cultural dimensions, management sets fixed pattern of working principles to influence employees in change practices, ensure changes in policies based on investigation, provide strong assessment for systematic risk management, and ensure the system of job accomplishment and reporting. Beside the individual features of employees, extent of environmental fit, stress realized because of job responsibility and working culture i.e. work relationship, and work-life conflict are responsible for work-behaviours of employees. Positive work attitude of employees results higher safety, better customer service and higher performance of business organization (Libraries, 2020; Harter, Schmidt, \& Hayes, 2002).

Bureaucratic culture is characterized with a clear chain of authority, highly regulated and systemized work. Employees under bureaucratic culture, required to perform tasks under the specified rules and procedures. Innovative culture encourages creativity, freedom, results-oriented and risk-taking environment while supportive culture enables open, fair and cooperative working environment with less distance between supervisors and employees.

Relationship between employees and line manager can be a highly positive along with trust i.e. consequence of work-culture in management which influences in organizational commitment (Sawithri, Nishanthi, \& Amarasinghe, 2017). Culture is crucial organizational factor for its success as it enhances employee satisfaction, loyalty and retention, increases productivity, improves teamwork and the financial performances of commercial banks (Rashid, Sambasivan, \& Johari, 2003). Ramdhani, Ramdhani, Ali and Ainisyifa (2017) emphasize on the need for developing corporate culture with adequate balance of teamwork, communication, training development and reward-recognition which helps to maintain efficiency, effectiveness and organizational productivity.

Both, weak and strong cultures have powerful influence on organizational behaviour, but in strong culture everyone knows the goals of the corporation and try to align with management's goals; in a weak culture member' goals are counter to management's direction or perhaps simply scattered and divergent (Deal \& Kennedy, 1982). Based on discussion, following hypotheses are set for the study:

H1a: Stronger the bureaucratic work-culture, weaker would be the employees' positive work behaviour.

$\mathrm{H} 1 \mathrm{~b}$ : Stronger the innovative work-culture, stronger would be the employees' positive work behaviour.

H1c: Stronger the supportive work-culture, stronger would be the employees' positive work behaviour. 
Job satisfaction is the positive feelings governed by an employee through the job itself and the job environment. If the expectations of an individual get fulfilled, the person gets satisfaction and the individual performs behaviour as expected by organization (Pitaloka, \& Sofia, 2014). Various factors like peer support, work condition, quality of supervisor, job achievement, and degree of responsibility are more significant predictors of job satisfaction (Yasin, Kerr, \& Wong, 2020). These factors are important domains of work-culture, thus, it can be argued that work-culture causes employee job satisfaction. Along with, grievance handling mechanism i.e. a part of work-culture also influences employee satisfaction and commitment (Fiorita, Bozeman, Young, \& Meurs, 2007). Job satisfaction can be increased with ample work-programs and practices for employee engagement (Khalaf, Hmoud, \& Obeidat, 2019). Good work-relationship enhances integrated communication among employees and the management. Integrated communication encourages each employee for positive work-behaviours i.e. creating and sharing ideas, views and opinions for improving current performance level, establishes the culture of recognition and acknowledgement for usable ideas, views and opinions which cause to increase in satisfaction. Moreover, work-culture provides sense of belongingness to each employee which increases their level of satisfaction.

Job satisfaction has strong positive relation with organizational commitment (Prasetio, Yuniarsih, \& Ahman, 2017; Morin, et al., 2011; Lavelle, et al., 2009; Ćulibrk, Delić, Mitrović, \& Ćulibrk, 2018). Job satisfaction increases the job involvement in employees (Ćulibrk, et al., 2018) and engagement (Khalaf, Hmoud, \& Obeidat, 2019) i.e. positive work-behaviour. Job satisfaction directly affects performance level, absenteeism and turnover intention. Satisfied employees reflect positive attitude towards management, leadership style, and organizational policy. Employee satisfaction affects both in personal as well as organizational performance (Bakotić, 2016) through positive work-behaviour i.e. willingness to take responsibility, initiating solving organizational problems, cooperation and collaborations. In this way, workculture influences employee job satisfaction and the job satisfaction influences positive workbehaviour. This situation encourages to test the mediating effect of job satisfaction in relation to work-culture and work-behaviour employees.

Job satisfaction mediates the relationship between non-monetary strategies and commitment (Mahmood, Akhtar, Talat, Shuai, \& Hyatt, 2019). Job satisfaction is the determinant of commitment as it has positive significant relationship with organization commitment while negative association with job turnover intention (Tarigan \& Ariani, 2015). Employees' satisfaction increases employees' job engagement. Job satisfaction leads for positive commitment (affective, normative, and continuances) but higher the satisfaction does not necessarily result higher level of commitment (Gautam, 2017). Work-culture may or may not fit with personal personality traits, personality traits affect satisfaction and which finally affect organizational citizenship behaviour (Ilies, Fulmer, Spitzmuller, \& Johnson, 2009). Suparjo and Darmanto (2015) also proved the mediating role of job satisfaction in relationship between work-culture and citizenship behaviour. Based on this, this study has set following hypotheses to examine the mediation effect of job satisfaction in relation between work-culture and employees' work behaviour. 
$\mathrm{H} 2 \mathrm{a}$ : Stronger the work-culture, stronger would be the employee satisfaction.

$\mathrm{H} 2 \mathrm{~b}$ : Stronger the work-culture, stronger would be the positive work behaviour.

$\mathrm{H} 2 \mathrm{c}$ : Stronger the employee job satisfaction, stronger would be the positive employees' work behaviour.

H3: Employee job satisfaction mediates the relationship between work-culture and employees' work behaviour.

\section{THEORETICAL FOUNDATION AND CONCEPTUAL FRAMEWORK}

Employees' satisfaction and their work behaviour of each individual is the consequence of sociological and psychological interaction; as theorized in terms of Social Exchange Theory (SET). SET claims that employees expect congenial, friendly, and professional relationship among organizational members i.e. managers, supervisors and employees for positive work experience, satisfaction and positive work behaviour. SET provides most influential paradigm to understand employees' workplace behaviour (Cropanzano \& Mitchell, 2005).

Social exchange relationship in the organization, as result of work-culture affects employees' commitment. Both social exchange and economic exchange dimensions positively affect commitment (Ozmen, 2019). Thus, for positive work-behaviour of employees, management should care on establishing good work-culture along with competitive economic rewards. This situation increases the significance of maintaining work-culture to direct employees' behaviour.

Wallach (1983) conceptualized the organizational culture with three subdomains: bureaucratic, innovative, and supportive culture as the basic guiding pillars at the workplace. In SMEs, managers and supervisors also adapt one of these three or one domain at a time for planning and decision making, communication, coordination, command and control. Thus, this study also followed these domains as the domain of workplace culture while positive and withdrawal behaviour are chosen as domain of work behaviour. Based on the facts discussed, following conceptual framework is proposed to examine:

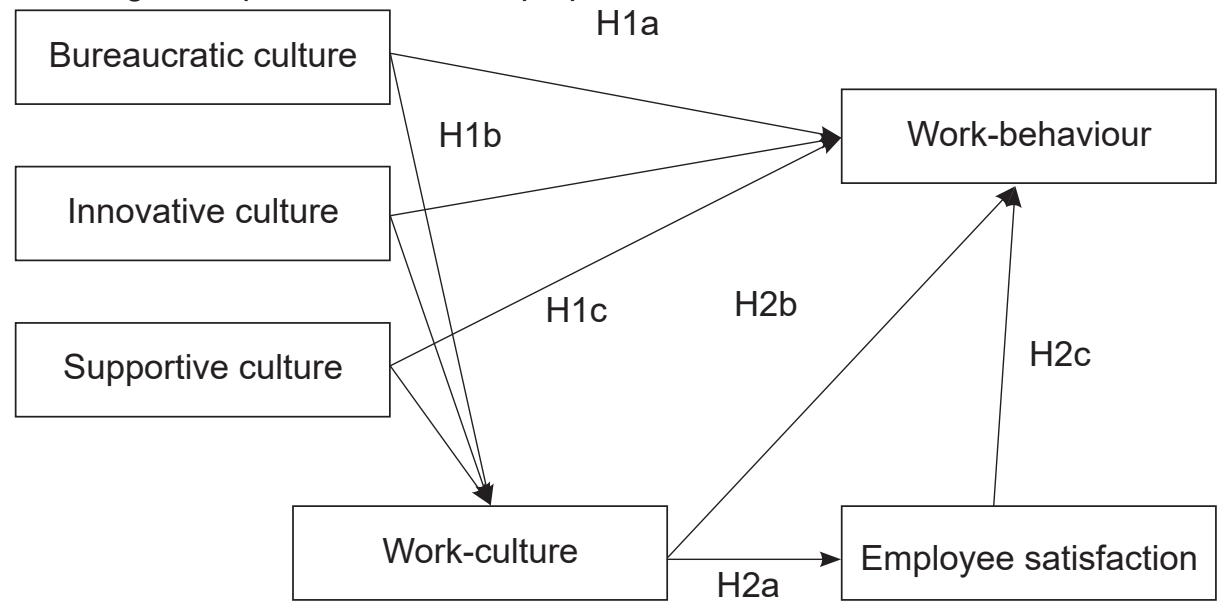

Figure 1. Research framework 


\section{METHODOLOGY}

\section{Population, sample and instrumentation}

Kathmandu based organizations categorized under Restaurants, Travels and Tours, Retail Trading shops, Bakery producers and Cold Storages with minimum 10 employees were taken as the population but based on personal approach and discussion with managers/supervisors, if the majority of employees could understand the construct and shown interest in participating in research were taken as the sample using purposive sampling technique. The questionnaire was verbally translated to help the respondents understand it wherever required.

Information regarding the construct of framework was collected through a survey questionnaire with 5-Point Likert Scale developed from the review of literature. Each construct of the framework retained five items except job satisfaction having only four items. Collected data were processed through a Factor Analysis with Principal Component Analysis and Varimax Rotation. Retained factors from Factor Analysis were processed with Conformity Factor Analysis (CFA) using AMOS for model fit test. Regression analysis was conducted for examining effect of predictors on predicting variables. Finally, the mediating effects were examined with Preacher and Hayes Process Macro. Respondents were given the assurance of maintaining anonymity to avoid the chances of response biases.

\section{Descriptive findings}

Total 435 respondents were approached purposively (as to confirm they understand the constructs, can maintain diversity in terms of responsibility and functional area) for collecting information but only 376 (86.43 percent response rate) usable responses were returned from 39 organizations. Responses were from various demographic groups of hierarchies like assistant, officer, assistant manager and manager.

Table 1

Demographic information of respondents

\begin{tabular}{llcccccc}
\hline \multirow{2}{*}{ Categorical variables } & \multicolumn{5}{c}{ Current position } & Total & Percentage \\
& & Assistant & Officer & A. Manager & Manager & & \\
\hline \multirow{2}{*}{ Gender } & Male & 78 & 97 & 39 & 11 & 225 & 59.84 \\
& Female & 85 & 44 & 18 & 4 & 151 & 40.159 \\
Ownership & Joint ownership & 60 & 46 & 16 & 4 & 126 & 33.51 \\
Structure & Single ownership & 103 & 95 & 41 & 11 & 250 & 66.489 \\
Total & & 163 & 141 & 57 & 15 & 376 & 100 \\
\hline
\end{tabular}

Table 1 provides demographic profile of respondents, out of 39 sample organizations, only in 15 organizations, there was a provision of manager and assistant managers (in few senior manager and managers). Among the total respondents, 59.84 percent respondents were male while 40.159 percent female; 33.51 percent from the organization 
having joint ownership (either Partnership or Joint Stock Company) and 66.489 percent from single ownership organizations. A majority of respondents were from sole ownership organizations.

\section{Preliminary analysis for goodness of fit}

To confirm the psychometric characteristics, confirmatory factor analysis (CFA) was conducted using maximum likelihood estimation. The results of CFA provided an evidence of good fit of proposed model $(X 2=335.131$, df $=245, p=0.000, X 2 / d f=$ 1.368, $\mathrm{CFI}=0.974, \mathrm{TLI}=0.971, \mathrm{GFI}=0.932, \mathrm{NFI}=0.910)$ and badness of fit $(\mathrm{RMSEA}$ $=0.039$ ) with $\mathrm{KMO}$ of Sampling Adequacy 0.786 and 61.515 percent variance explained by all constructs which entitles that indicators are loaded significantly on intended latent variables. These results provided evidence of convergent validity as per conditions suggested by Hair, Black, Babin and Anderson (2014). Standardized factor loading, reliability and validity of the constructs fulfil the criteria for path analysis. The studied model was found to have sufficient internal consistency and validity of constructs.

Table 2

Descriptive statistics and validity concern

\begin{tabular}{lllllllllllll}
\hline Construct & Mean & SD & Alpha & CR & AVE & MSV & MaxR (H) IC & SC & BC & JS & WB \\
\hline IC & 3.844 & 0.544 & 0.833 & 0.834 & 0.502 & 0.029 & 0.837 & 0.708 & & & & \\
SC & 3.89 & 0.589 & 0.833 & 0.834 & 0.503 & 0.006 & 0.841 & -0.04 & 0.709 & & & \\
BC & 4.008 & 0.644 & 0.833 & 0.835 & 0.503 & 0.006 & 0.839 & -0.02 & -0.075 & 0.709 & & \\
JS & 3.902 & 0.629 & 0.787 & 0.822 & 0.566 & 0.029 & 0.994 & 0.169 & -0.013 & -0.054 & 0.752 & \\
WB & 3.639 & 0.549 & 0.838 & 0.84 & 0.513 & 0.004 & 0.841 & -0.026 & -0.024 & 0.055 & 0.063 & 0.716 \\
\hline
\end{tabular}

Notations. IC - Innovative culture, SC - Supportive Culture, BC - Bureaucratic culture, JS - Job Satisfaction, WB - employee Work-behavior

From table 2, greater values of AVE of all the constructs more than 0.5 indicate that there is no concern of convergent validity $(C R>0.7, A V E>0.5, C R>A V E)$ as suggested by Fornnell and Larcker (1981) and Netemeyer, Bearden, and Sharma (2003) cited in Terglav, Ruzzier, and Kase (2016). Similarly, there is no issue of the discriminant validity as the construct's squared correlations with other constructs are greater than MSV of each construct (AVE > MSV). These findings support that each construct is distinct from other constructs and fit for the model.

\section{Hypothesis testing}

Work-cultures namely innovative culture, supportive culture, and bureaucratic culture were found to have predictive power for employees' work behaviour with a significant regression results $(F(3,372)=32.523, p<0.001)$ with an adjusted $R^{2}$ of 0.223 . Among three predictors, supportive culture (coeffi. $=0.243, p<0.000$ ) was found to have highest significant contribution on creating positive work behaviour followed by bureaucratic culture (coeffi. = $0.171, p<0.001$ ) and innovative culture (coeffi. $=0.112, p=0.001)$. These results support to accept $\mathrm{H}_{1 \mathrm{a}}, \mathrm{H}_{1 \mathrm{~b}}$ and $\mathrm{H}_{1 \mathrm{c}}$. (See Appendix 1) 
Regarding the relationship between components of work-culture and job satisfaction, significant regression coefficients have found $(F(3,372)=4.943$, $p<0.002$ ) with an adjusted $R^{2}$ of 0.219 . Among three predictors, innovative workculture (coeffi. $=0.227, p<0.000$ ) was found to have highest significant contribution on creating positive work behaviour followed by supportive work-culture (coeffi. = $0.009, p<0.001$ ) and bureaucratic work-culture (coeffi. $=-0.003, p=0.002$ ) (See Appendix 2). These results support to accept $\mathrm{H}_{2 \mathrm{a}}$. This results that increase/strong in innovative and supportive culture increases employee satisfaction while increase/ strong in bureaucratic culture decreases the job satisfaction.

To examine the mediation role of job satisfaction in the relationship between workculture and work behaviour, Process Macro was used as per Preacher and Hayes (2008). Job satisfaction was found to have direct significant relationship with employees' work behaviour with significant total direct effect $(0.098, t=1.991, P=0.000, \mathrm{LLCl}=0.381$ $\mathrm{ULCl}=0.015)$; significant relation between work-culture to job satisfaction with total direct effect $(0.199, t=2.033, P=0.004, L L C l=0.007 \mathrm{ULCl}=0.393)$. These results support to accept $\mathrm{H}_{2 \mathrm{~b}}$ and $\mathrm{H}_{2 \mathrm{c}}$. Total indirect effect of job satisfaction in relation between work-culture and work behaviour as $(0.082, \mathrm{LLCl}=-0.0108 \mathrm{ULCl}=0.0341)$ indicating that there was not significant indirect relationship with bootstrapping, and 95 percent level of confidence providing no evidence to accept $\mathrm{H}_{3}$. This indicates that there is no mediation role of job satisfaction in between the relationship between work-culture and employees' work behaviour, hence, the hypothesis $\mathrm{H}_{3}$ cannot be accepted.

Table 3

Mediating effects of job satisfaction

\begin{tabular}{llllll}
\hline Direct Relations & Coef. & $\mathrm{t}$ & $\mathrm{p}$ & $\mathrm{LLCl}$ & $\mathrm{ULCl}$ \\
\hline WC -> JS & 0.199 & 2.033 & 0.004 & 0.007 & 0.393 \\
JS -> WB & 0.098 & 1.991 & 0.000 & 0.381 & 0.015 \\
Indirect total effect WC->WB & 0.0082 & & & -0.011 & 0.034 \\
\hline
\end{tabular}

From Table 3, result supports to reject the mediating effect of job satisfaction as there is zero in between $\mathrm{LLCl}$ and $\mathrm{ULCl}$, concluding the insignificant mediating relationship of job satisfaction in relationship between work-culture and employee work behaviour. This result, then, suggests that by different types of work-culture, employee satisfaction as well as the employees' work behaviour can be regulated providing no mediation effect of job satisfaction.

\section{DISCUSSION OF THE RESULTS AND CONCLUSION}

Results from the data analysis revealed that three types of work-culture: supportive culture, innovative culture and bureaucratic culture, significantly affect employees' work-behaviour which is supported by the findings of Messner (2013). As suggested by Messner (2013), this finding emphasises on establishing supportive work-culture with high priority. As the finding revealed supportive culture in the organization affects 
employees' work behaviour more significantly in comparison to the innovative and bureaucratic culture; management need to develop harmonious relations to support in job accomplishment of every employee. Results indicate that employees wish support in accomplishing their responsibilities from their managers, supervisors as well as the coworkers. As the varying degree of positive or negative influence, supportive work-culture increases sense of belongingness among the employees which tends to encourages to be more positive in their responsibility, customers and organization. Bureaucratic culture practices close supervision, strict rules and regulations, and strict command and discipline which tend to direct employees' behaviour at the right track by force or compulsion and negative motivation. As a result, study found to have positive significant relationship with employees' work behaviour while bureaucratic work-culture establishes the negative job satisfaction. This result is similar with findings of Kiral and Kacar (2016). Bureaucratic work-culture as stands second more significant predictor of work behaviour, may influence through compulsion especially to less dedicated, less focused and having low or no self-determination. Regarding the innovative work-culture, in SMEs, it is expected to have job autonomy for better service, new product design within regular expenses, and having better relationship with customers; as innovation leads higher job satisfaction (Park, Tseng, \& Kim, 2016).

As asserted by Chan and Lukoto (2016), findings of this study claim that employees perceive positive to the innovative culture and behave innovative behaviour. Thus, for the SMEs with inadequate financial resources for invention of new product and services, employees with positive work-behaviour can be source of competitive advantages as they focus on identification and development of new ways of serving customers, new way of arranging jobs, equipment and machinery, and modification in applications and instructions. Employees with such opportunities can be satisfied and hence feel the sense of value, self-esteem and accomplishment for being positive for organizational success. These findings of the study also support the findings of Sawithri, Nishanthi, and Amarasinghe (2017).

Result examined the role of employee job satisfaction on predicting the employees work behaviour not only for permanent turnover but also for work related attitude and behaviour with customers as well as co-workers which also supports the conclusion of Tarigan and Ariani (2015). Organizations should focus their efforts to establish and enhance special work-culture characterized with mutual support. Thus, this study argues the need for establishing and enhancing special supporting relationship with employees to direct their behaviour positive for organizational success.

\section{PRACTICAL AND THEORETICAL IMPLICATION}

This study could be significant to all the SMEs suffering from the problem of employee turnover, deviant behaviour and even the situation of having static performance. Findings of this research can be guidelines to the owners of SMEs regarding work-practices how employees need to treat to satisfy them optimally and concentrate their positive energy 
to the benefit of business through positive work behaviour. More importantly, this study stresses the need to establish and maintain supportive work-culture.

This research also emphasizes on the need to establish the scope of social exchange theory (SET) as it advocates that the employees' behave reciprocate as they perceive are behaving by their management. Simply, for positive work-behaviour of employees, there should be supportive work-culture.

\section{Research limitations and future scope}

This study lays focus on aggregate level of work-culture, employee satisfaction and employees' work-behaviour in SMEs in Kathmandu. Future researchers can segregate different sectors within SMEs as these sectors may promote different work-cultures. Within innovation culture, researchers can have further investigation in opportunity exploration, idea generation, and idea championing and idea realization in relations to job satisfaction and work-behaviour. Additionally, future researchers can add scope by splitting the employees' work-behaviour in micro levels.

\section{Acknowledgments}

I sincerely acknowledge the support of all respondents for their responses, managers who allowed their subordinates to respond the survey questionnaire. I also pay my sincere gratitude to all people who directly and indirectly facilitated me in data collection, analysis and interpretation.

\section{REFERENCES}

Allen, N., \& Meyer, J. P. (1990). The measurement and antecedents of affective, continuance and normative commitment to the organisation. Journal of Occupational Psychology, 63, 1-18.

Angle, H., \& Perry, J. (1981). An empirical assessment of organisational commitment and organizational effectiveness. Administrative Science Quarterly, 26, 1-13.

Bakotić, D. (2016). Relationship between job satisfaction and organisational performance. Economic Research-Ekonomska Istraživanja, 29(1), 118-130. doi:10.1080/1331677X 2016.1163946

Bista, I. (2019, September 26). SMEs financing in Nepal: five key findings of the report. Retrieved July 24, 2020, from Nepal Economic Forum: https://nepaleconomicforum.org/ neftake/.

Buchanan, B. (1974). Building organizational commitment: The socialization of managers in work organizations. Administrative Science Quarterly, 19, 533-546.

Cameron, K. S., \& Quinn, R. E. (2011). Diagnosis and Cchanging Organizaitonal Culture: based on the Competing Values Framework (3rd ed.). San Fransisco: Jossey-Bass Publishers.

Chan, K.Y., \& Lukoto, K.(2016). The perception of innovative organisational culture and its influence on employee innovative work behaviour. PICMET '16: Technology Management for Social Innovation, 972-977. doi:10.1109/PICMET.2016.7806707

Cropanzano, R., \& Mitchell, M. S.(2005). Social exchange theory: an interdisciplinary review. Journal of Management, 31(6), 874-900. doi:10.1177/0149206305279602

Ćulibrk, J., Delić, M., Mitrović , S., \& Ćulibrk, D. (2018). Job satisfaction, organizational commitment and job involvement: the mediating role of job involvement. Frontier in Psychology, 9(132), 1-12. doi:10.3389/fpsyg.2018.00132 
Deal, T., \& Kennedy, A. A. (1982). Corporate Cultures. MA: Addison-Wesley, Reading.

Delaney, J., \& Huselid, M. (1996). The impact of human resource managment practices on perceptions of organizational performance. The Academy of Management Journal, 39(4), 949-969.

Denison, D. (1990). Corporate Culture and Organisational effectiveness. New York: John Wiley.

Dessler, G. (1999). How to earn your employees' commitment. Academy of Management Executive, 13(2), 58-67. doi:10.5465/ame.1999.1899549

Fiorita, J. A., Bozeman, D. P., Young, A., \& Meurs, J. A. (2007). Organizational commitment, human resource practices and organizational characteristics. Journal of Managerial Issues, 19(2), 186-207.

Gautam, P. K. (2017). Issue of organizational commitment : evidence from Nepalese banking industry. Management Dynamics, 20(1), 118-129.

Hair, J. F., Black, W. C., Babin, B. J. \& Anderson, R. E. (2014). Multivariate Data Analysis. Edinburgh Gate Harlow Essex, England: Pearson Education Limited.

Harter, J. K., Schmidt, F. L. and Hayes, T. L. (2002). Business-unit-level relationship between employee satisfaction, employee engagement, and business outcomes: a meta-analysis. Journal of Applied Psychology, 87(2), 268-279. doi:10.1037//0021-9010.87.2.268

Hershcovis, M. S., Turner, N., Barling, J., Arnold, K. A., Dupre, K. E., Inness, M., LeBlanc, M. M., \& Sivanathan, N. (2007). Predicting workplace aggression: A meta-analysis. Journal of Applied Psychology, 92(1), 228 -238. doi:10.1037/0021-9010.92. 1.228

Ilies, R., Fulmer, I. S., Spitzmuller, M., \& Johnson, M. D. (2009). Personality and citizenship behavior: the mediating role of job satisfaction. Journal of Applied Psychology, 94(4), 945959. doi:https://doi.org/10.1037/a0013329

Industrial Policy (2010). Ministry of Industry, Nepal.

Isa, M. F., Ugheoke, S. O., \& Noor, W. S. (2016). The influence of organizational culture on employees' performance: evidence from oman. Journal of Entrepreneurship and Business, 4(2), 1-12. doi:10.17687/JEB.0402.01

Kalemci, R. A., Kalemci-Tuzun, I., \& Ozkan-Canbolat, E. (2019). Employee deviant behavior: role of culture and organizational relevant support. European Journal of Management and Business Economics, 1-17. doi:10.1108/EJMBE-11-2018-0125

Khalaf, R. K., Hmoud, H. Y., \& Obeidat, B. (2019). Reviewing the mediating role of job satisfaction on the effect of employee engagement on organizational performance. Journal of Social Sciences, 8(1), 7-23. doi:10.25255/jss.2019.8.1.7.23

Kiral, E., \& Kacar, O. (2016). The relationship between teachers' school commitment and school culture. International Education Studies, 9(12), 90-108. doi: 10.5539/ies. v9nl2p90

Kristof-Brown, A. L., Zimmerman, R. D., \& Johnson, E. C. (2005). Consequences of individuals' fit at work: a meta-analysis of person-job, person-organization, person-group, and personsupervisor fit. Personnel Psychology, 58, 281-342. doi:10.1111/j.1744-6570.2005.00672.x

Lavelle, J., Brockner, J., Konovsky, M. A., Price, K. H., Henley, A. A., Taneja, A., \& Vinekar, W. (2009). Commitment, procedural fairness, and organizational citizenship behaviors: a multifoci analysis. Journal of Organizational Behavior, 30, 337-357. doi: 10.1002/job.518

Libraries (2020). Retrieved from work attitude: https://open.lib.umn.edu/ organizational behavior/ chapter/4-2-work-attitudes/.

Lok, P., \& Crawford, J. (2004). The effect of organizational culture and leadership style on job satisfaction and organizational commitment: a cross national comparison. Journal of Management Development, 23(4), 321-338. 
30 I PYC Nepal Journal of Management, August 2020 Vol. XIII, No. 1

Maheshwari, M., Samal, A., \& Bhamoriya, V. (2020). Role of employee relations and sustainability in MSME firms. International Journal of Productivity and Performance Management, aheadof-print(ahead-of-print). doi:10.1108/IJPPM-12-2019-0599

Mahmood, A., Akhtar, M. N., Talat, U., Shuai, C., \& Hyatt, J. C. (2019). Specific HR practices and employee commitment: the mediating role of job satisfaction. Employee Relations: The International Journal, 41(3), 420-435. doi:10.1108/ER-03-2018-0074

Mathieu, J. E., \& Zajac, D. M. (1990). A review and meta-analysis of the antecedents, correlates and consequences of organizational commitment. Psychological Bulletin, 108, 171-194.

Messner, W. (2013). Effect of organizational culture on employee commitment in the Indian IT services sourcing industry. Journal of Indian Business Research, 5(2). doi:10.1108/ 17554191311320764

Meyer, J., \& Allen, N. (1997). Commitment in the workplace: theory, research and application. London: Sage Publication.

Miller, B. K., Rutherford, M., \& Kolodinsky, R. (2008). Perceptions of organizational politics: A meta-analysis of outcomes. Journal of Business and Psychology, 22(3), 209-222. doi:10.1007/s10869-008-9061-5

Morin, A. J., Vandenberghe, C., Bounderias, J. S., Madore, I., Morizot, J., \& Tremblay, M. (2011). Affective commitment and citizenship behaviors across multiple foci. Journal of Managerial Psychology, 26(8), 716-738. doi:10.1108/02683941111181798

MSG. (2020, July 10). Employee behaviour: an overview. Retrieved from Management Study Guide: https://www.managementstudyguide.com/employee-behaviour.htm.

O'Reilly, C., \& Chatman, J. (1986). Organisational commitment and psychological attachment: the effects of compliance, identification and internalization on pro-social behavior. Journal of Applied Psychology, 71, 492-499.

Ozmen, Y. S. (2019). How the exchange relationship affects employee commitment: the mediating role of organizational trust. Journal of Management Development, 38(6), 501-516. doi:10.1108/JMD-08-2018-0220

Park, S., Tseng, Y., \& Kim, S. (2016). The impact of innovation on job satisfaction: evidence from US Federal agencies. Asian Social Science, 12(1), 274-286. doi:10.5539/ ass.v12n1p274

Pitaloka, E., \& Sofia, I. P. (2014). The affect of work environment, job satisfaction, organization commitment on ocb of internal auditors. International Journal of Business, Economics and Law, 5(2), 10-18.

Poznanski, P. J., \& Bline, D. M. (1997). Using structural equation modeling to investigate the causal ordering of job satisfaction and organizational commitment among staff accountants. Behavioral Research Accounting, 9, 32-43.

Prasetio, A. P., Yuniarsih, T., \& Ahman, E. (2017). Job satisfaction, organizational commitment and organizational citizenship behaviour in state-owned banking. Universal Journal of Management, 5(1), 32-38. doi:10.13189/ujm.2017.050104

Preacher, K. J., \& Hayes, A. F. (2008). Asymptotic and resampling strategies for assessing and comparing indirect effects in multiple mediator models. Behavior Research Methods, 40(3), 879-891. doi:10.3758/BRM.40.3.879

Ramdhani, A., Ramdhani, M. A., \& Ainisyifa, H. (2017). Model conceptual framework of corporate culture influenced on employees commitment to organization. International Business Management, 11(3), 826-830.

Rashid, M. Z., Sambasivan, M., \& Johari, J. (2003). The influence of corportate culture and organisational committment on performance. Journal of Management Development, 22(8), 708-728. doi: 10.1108/02621710310487873

Ravasi, D., \& Schultz, M. (2006). Responding to organizational identity threats: exploring the role of organizational culture. Academy of Management Journal, 49(3), 433-458. 
Robbins, S. P., \& Judge, T. A. (2013). Organizational Behavior (15th ed.). Delhi: Pearson.

Samwel, J. O. (2018). Effect of employee relations on employee performance and organizational performance-study of small organizations in tanzania. Global Journal of Management and Business Research: Administration and Management, 18(8), 31-40. Retrieved from https:// www.journalofbusiness.org/index.php/GJMBR/article/ view/ 2578/2479.

Sawithri, L. D., Nishanthi, H. N., \& Amarasinghe, K. G. (2017). The impact of employer-employee relations on employee commitment: a case from Sri Lanka. Kelaniya Journal of Human Resource Management, 12(2), 174-192. doi:10.4038/kjhrm.v12i2.38

Seppälä, E., \& Cameron, K. (2015, December 01). Proof that Positive Work Cultures are more Productive. Retrieved from Harvard Business Review: https://hbr.org/2015/12/proof -thatpositive-work-cultures-are-more-productive.

Sidekicker. (2020, June 30). What is workplace culture really? Retrieved from Sidekicker. com: https://sidekicker.com/au/blog/workplace-culture-really/\#: :text=A\%20 good\%20 workplace $\% 20$ culture $\% 20$ provides,satisfied $\% 20$ employees $\% 20$ and $\% 20$ increases $\% 20$ productivity.

Spinelli, S., \& Adams, R. J. (2016). New venture creation (10th ed.). New York: McGraw Hill Education.

Stephen, S., \& Adams, R. J. (2016). New venture creation :entrepreneurship for the 21st century . McGraw Hills Education. Retrieved from https://b-ok.asia/book/ 5003851/ 62535d.

Suparjo, S., \& Darmanto, S. (2015). Mediating role of jobs satisfaction among organizational commitment, organizational culture and organizational citizenship behavior : empirical study on private higher education in central Java, Indonesia. Journal of Research in Marketing, 4(1), 289-296.

Tabane, T., Bosch, A., \& Roodt, G. (2013). Organisation value-person value congruence and the relation to organisational commitment. South African Journal of Labour Relations, 37(1), 39-60.

Tamir, M., \& Mauss, I. B. (2011). Social cognitive factors in emotion regulation: implications for well-being. Emotion Regulation and Well-Being, 1-35. doi:10.1007/978-1-4419-6953-8_3

Tarigan, V., \& Ariani, D. W. (2015). Empirical study relations job satisfaction, organizational commitment and turnover intention. Advances in Management \& Applied Economics, 5(2), 21-42.

Van der Post, W., deConing, T., \& Smit, E. V. (1998). The relationship between organizational culture and financial performance: some South African evidence. South African Journal of Business Management, 29(1), 30-41.

Verquer, M. L., Beehr, T. A., \& Wagner, S. H. (2003). A meta-analysis of relations between person-organization fit and work attitudes. Journal of Vocational Behavior, 63, 473-489. doi:10.1016/S0001-8791(02)00036-2

Wallach, E. J. (1983). Individuals and organizations: the cultural match. Training and Development Journal, 37, 29-36.

Yasin, Y. M., Kerr, M. S., \& Wong, C. A. (2020, May). Factors affecting job satisfaction among acute care nurses working in rural and urban setting. JAN Learning Global Nursing Research, 1-10. doi:10.1111/jan.14449

Zaitouni, M. (2013). Do we really behave the same way? assessing the three dimensions of organizational commitment as antecedents of human resource practices in a non-western context. International Journal of Business and Social Research (IJBSR), 3(5), 256-280.

Zakayo, C. M. (2018). Effects of organizational culture on employee productivity in state department of livestock Nakaru Country-Kenya. International Journal of Trend in Scientific Research and Development (IJTSRD), 3(3), 241-246. Retrieved from www.ijtsrd.com. 
32 I PYC Nepal Journal of Management, August 2020 Vol. XIII, No. 1

\section{APPENDICES}

\section{Appendix 1}

Model summary and Coefficients predicting employee work-behaviour by work-culture Coefficients $^{a}$

\begin{tabular}{|c|c|c|c|c|c|c|c|c|c|}
\hline \multirow[t]{2}{*}{ Model } & & \multicolumn{3}{|c|}{ Unstandardized Coefficients } & \multirow{2}{*}{\multicolumn{3}{|c|}{$\frac{\text { Standardized Coefficients }}{\text { Beta }}$}} & \multirow{2}{*}{$\mathrm{t}$} & \multirow{2}{*}{ Sig. } \\
\hline & & & B & Std. Error & & & & & \\
\hline & \multicolumn{2}{|c|}{ (Constant) } & 3.568 & 0.341 & & & \multicolumn{2}{|r|}{10.474} & 0.000 \\
\hline & \multicolumn{2}{|c|}{ S_Bc } & 0.171 & 0.044 & \multicolumn{2}{|c|}{0.172} & \multicolumn{2}{|r|}{0.905} & 0.001 \\
\hline & \multicolumn{2}{|c|}{ S_lc } & 0.112 & 0.052 & \multicolumn{2}{|c|}{0.115} & \multicolumn{2}{|r|}{0.284} & 0.001 \\
\hline & \multicolumn{2}{|c|}{ S_Sc } & 0.243 & 0.048 & \multicolumn{3}{|c|}{0.253} & 0.171 & 0.000 \\
\hline \multicolumn{10}{|c|}{ a Dependent Variable: $S_{-} W e B$} \\
\hline \multicolumn{10}{|c|}{ Model Summary } \\
\hline \multirow[t]{2}{*}{$\mathrm{R}$} & R Square & $\begin{array}{c}\text { Adjusted R } \\
\text { Square }\end{array}$ & Std. Error & \multicolumn{6}{|c|}{ Change Statistics } \\
\hline & & & & $\begin{array}{c}\mathrm{R} 2 \\
\text { Change }\end{array}$ & F Change & $\mathrm{df1}$ & $\mathrm{df} 2$ & & $\begin{array}{l}\text { Sig. } \\
\text { Change }\end{array}$ \\
\hline $0.478 a$ & 0.229 & 0.223 & 0.055 & 0.003 & 32.52 & 3 & 372 & & 0.000 \\
\hline
\end{tabular}

a Predictors: (Constant), S_Sc, S_Ic, S_BC, Dependent: Work-behaviour

Appendix 2

Model summary and Coefficients predicting employee satisfaction by work-culture Model Summary

\begin{tabular}{ccccccccc}
\hline$R$ & R Square & $\begin{array}{c}\text { Adjusted R } \\
\text { Square }\end{array}$ & Std. Error & \multicolumn{5}{c}{ Change Statistics } \\
\hline & & & $\begin{array}{c}\text { R 2 } \\
\text { Change }\end{array}$ & F Change & df1 & df2 & Sig. F Change \\
$0.474 a$ & 0.225 & 0.219 & 0.035 & 0.038 & 4.943 & 3 & 372 & 0.002 \\
\hline
\end{tabular}

a Predictors: (Constant), S_Sc, S_Ic, S_BC

Coefficients $^{\mathrm{a}}$

\begin{tabular}{|c|c|c|c|c|c|c|}
\hline \multirow{2}{*}{ Model } & & \multicolumn{2}{|c|}{ Unstandardized Coefficients } & \multirow{2}{*}{$\begin{array}{c}\text { Standardized } \\
\text { Coefficients Beta }\end{array}$} & \multirow{2}{*}{$\mathrm{t}$} & \multirow{2}{*}{ Sig. } \\
\hline & & B & Std. Error & & & \\
\hline & (Constant) & 3.008 & 0.341 & & 7.884 & 0.000 \\
\hline & S_Bc & -0.003 & 0.044 & -0.004 & -0.006 & 0.002 \\
\hline & S_lc & 0.227 & 0.052 & 0.229 & 3.284 & 0.000 \\
\hline & S_Sc & 0.009 & 0.048 & 0.011 & 1.197 & 0.000 \\
\hline
\end{tabular}

a Dependent Variable: Satisfaction 